\title{
Revenue diversification and bank profitability: study on Indonesian banks
}

\author{
Muhammad Zaki Ashyari*, Rofikoh Rokhim \\ Department of Management, Faculty of Economics \& Business, Universitas Indonesia, Jakarta, Indonesia \\ ${ }^{*}$ Corresponding author: m.zaki42@ui.ac.id
}

\begin{abstract}
Bank has traditional activities that generate interest income, and non-traditional activities such as underwriting and trading securities, broker-agent, and investment banking, and other activities that generate non-interest income. This paper investigates traditional and non-traditional activities and the impact of revenue diversification on bank profitability. We use the data from the Indonesia banking industry 2007-2016 to measure the impact of revenue diversification, commission revenue, trading revenue, and other revenue on bank return on asset and return on equity. We find that revenue diversification increases bank profitability. However, all the non-interest income has a negative correlation on bank profitability.
\end{abstract}

Keywords: Revenue diversification, profitability, Indonesian banks \begin{tabular}{ll}
\hline JEL Classification Code: G21 DOI: 10.20885/jsb.vol24.iss1.art3
\end{tabular}

\section{Introduction}

The development of the banking sector over the last few years has changed significantly. These changes include the business model of a banking company that no longer relies on interest income, as well as the emergence of other products offered by banking companies. Not only does it create opportunities, but it certainly has an impact on competition in the industry that demands banks to expand their activities and business lines aside from the traditional activities that generate interest income. So far, the main income of commercial banks is derived from interest income, but this began to shift to an income with a more diverse structure. The bank began to diversify by relying on other sources of income such as by conducting other business activities such as underwriting and trading securities, broker-agent, and investment banking, and other activities that generate non-interest income (Meslier et al., 2014).

According to Krismanji (2017), the Product Diversification strategy itself can affect company performance while diversification in the banking sector has three dimensions: (i) Financial products and services diversification (ii) Geographical diversification, (iii) Business line diversification. (Mercieca et al., 2007). Diversification refers to the increase in the results of service costs, trading profit activities, and other non-interest income in the net operating income of a bank.

Income diversification according to the theory in the financial world itself should create a smaller level of risk and increase risk-adjusted performance in banking companies (Gürbüz,, et al., 2013). Some previous studies find that income diversification increases bank profitability and efficiency (DeYoung, 2004; Rogers \& Wright 1998). However some empirical studies, also show that the increase in non-interest income tends to increase profitability as well, but it is followed by an increase in risk level (Stiroh, 2004; Stiroh and Rumble, 2006; Lepetit et al., 2008). Where studies are also limited in describing the conditions occurring within developing countries. There are still results that show different conclusions as according to De Young and Roland (2001) on observations of banks found in the United States showed that increased diversification of income is negatively related to the level of risk. Meanwhile studies on developing countries are still a bit. Like Meslier et al. (2014) which conducted empirical studies on banks located in the Philippines, Pennathur et al. (2014) 
conducted an empirical study on banks located in India that find a benefit of increasing revenue diversification and non-interest income to bank profitability.

The banking industry in Asia itself experienced significant structural changes after the Asian crisis in 1997 due to the rapid and multiplicity of bank developments (Panh et al., 2016). It was also followed by deregulations on banking companies in Indonesia that encouraged competition in the banking industry in Indonesia. The banking competition becomes tights, namely for the biggest bank in Indonesia (Rokhim, 2017). The competition between banking companies here also encourages companies to diversify their opinions (Meslier et al., 2014). Using the data from 2004-2009 in Indonesia, Mutiara and Irwan (2016) find that income diversification and non-interest income doesn't bring benefit to company profitability.

Seeing the difference in results found by previous studies, and based on that background, this paper will examine the effects of income diversification and non-interest income levels on profitability in banking companies in Indonesia using annual data from 2007 to 2016 since, after financial crises in 2007, bank tends to increase their non-interest income.

\section{Literature Review}

\section{Income Diversification}

Income diversification refers to the intention of the company to expand its non-interest income so that the company's revenue does not only focus on the traditional income, which is the interest income (Va \& Ofekb, 1995; Winton, A., 1999). According to Froot and Stein (1998) diversification is a way to maintain risk and also reduce financial distress. According to Li and Zhang (2013), previous studies on income diversification have found that non-interest income can increase bank profitability and earnings stability, and another verifiable benefit is to reduce bank risk. Smith et al. (2003) found out that non-interest income increased the profit stability in the banking industry in Europe by observing the banking system in European countries during 1994-98. Smith et al. (2003) empirically confirmed that verifiable benefits can be achieved by combining non-interest income and interest income by European banks. They concluded that non-interest income-generating activities have the potential to stabilize bank earnings, increase company profitability and can reduce bank risk.

Many argue that an increase in non-interest income ratio will help the bank to improve its profitability and efficiency. This is proven by research conducted by DeYoung \& Rice (2004) and Rogers (1998) which indicates that large amounts of fee-based or non-traditional products or services increased bank efficiency in the 1980s and 1990s. On the other hand, other studies focusing on banks in the United States found that the increased involvement of companies in activities related to noninterest income will lead to increased profitability in the company, but on the other hand, because of the volatility of this activity, it also raises risks to the company. As DeYoung and Roland (2001) have conducted, Stiroh (2004), and Stiroh and rumble (2006) (as quoted in Meslier et al, 2014) in banks in the United States found that the higher the non-interest income of a bank, the volatility of the return of that bank will increase. Consistent with the research on US banks, banks in European countries also experienced an increased risk when banks increased the non-interest income (Lepetit et al., 2008). De Jonghe (2010) and Mercieca et al. (2007) found that revenue shifts in non-interest income at banks in European countries did not yield any benefits.

Consistent with the research on US banks, banks in European countries also experienced an increased risk when banks increased the non-interest income (Lepetit et al., 2008). De Jonghe (2010) and Mercieca et al. (2007) found that revenue shifts in non-interest income at banks in European countries did not yield any benefits. The study found that the ownership structure will determine the amount of non-interest income proposition to the bank, which will also determine the level of risk in the bank. Sanya and Wolfe (2011) used the GMM system method by observing 11 developing countries to see the impact of revenue verified on firm performance. The results of this study indicated that the shift of income to non-interest income. Meslier et al. (2014) proved that the shift in earnings 
to non-interest income is positively related to bank earnings, especially when banks play an active role in trading government securities.

\section{Methods}

\section{Data Collection and Sampel Selection}

This study uses a sample of commercial banks in Indonesia listed on the stock exchange. Banking data and macroeconomics were obtained from the Datastream database for the period 2007-2016. We use 18 banks in Indonesia that have revenue from various activities in non-interest income products. We select samples based on two criteria: (1) the availability and completeness of the data, therefor bank must have at least data from eleven years. (2) The noninterest income component must be positive to measure the share of non-interest income activities.

\section{Definition of Variables}

\section{Dependent variables}

The dependent variable in this study used to describe the return on the operationalization of bank assets can be illustrated by ROA and ROE. The author used a reference to the research of Meslier et al. (2014).

\section{Return on asset}

The ROA variable is the ratio used to measure the ability of a company's assets to generate Net Income. It can be calculated by dividing the company's net income by its total assets. To calculate bank profitability the author used the average asset to calculate the Return on Assets.

$R O A=\frac{\text { Net Income After } T a x}{\text { Average Total Asset }}$

Following the research of Meslier et al. (2014), ROA describes the profitability of bank operations. Data on bank asset returns in period t-1 were obtained from Datastream.

\section{Return on equity}

The ROE variable is the ratio used to measure the firm's equity capability to generate Net Income. It can be calculated by dividing the company's net profit by its total equity. To calculate bank profitability the author uses the average total equity to calculate Return on Equity..

$R O E=\frac{\text { Net Income After } \text { Tax }}{\text { Average Total Equity }}$

Following the research of Lee et al. (2014), ROE describes the profitability of bank operations to shareholder funds. Data on bank asset returns in period t-1 were obtained from Datastream.

\section{Independent variables}

\section{Diversification measure}

Referring to Lee et al. (2014) to measure the income diversification of this study, we can use the Herfindahl-Hirschman Index. So, following the research, the author made changes in the measurement of non-interest income, where the diversification of non-interest income is done by making it a separate variable to measure diversification. Thus, in this study, the income was gained by:

$D I V=1-\left(\left(\frac{I N T}{T O R}\right)^{2}+\left(\frac{\text { COMM }}{T O R}\right)^{2}+\left(\frac{T R A D}{T O R}\right)^{2}+\left(\frac{O T H}{T O R}\right)^{2}\right)$

The income diversification, using the Herfindahl-Hirschman Index indicator, is obtained by calculating the interest income and non-interest income on total operating income. INT (interest 
revenue) ratio was earned by dividing interest income with total operating income; COM (net commission revenue) ratio was earned by dividing commission income by total operating income; TRAD (Net trading revenue) ratio was earned by dividing commission income with total operating income. OTH (Net other revenue) the ratio was earned by dividing the other income with total operating income.

\section{Non-interest income activity}

Measuring non-interest income levels can be calculated using a ratio that represents a portion of one component of non-interest income to total operating income. Non-interest income sources consist of three types: commission revenue, trading revenue, and other revenue. Therefore, in this study, to measure the level of income concentration in the three types of activities, the author divided the measurement in three independent variables referring to Lee et al. (2014), the three variables are COMM (Commission revenue/total operating income), TRAD (Trading revenue/total operating income), and OTH (Other revenue/total operating income). The data can be obtained through the financial statements of the related bank and the Datastream.

\section{Control Variables}

\section{Assets}

Referring to the research of Chiorazzo et al. (2008), Stioroh and Rumble (2006) asset is a control variable that aims to describe the characteristic size of a bank in the associated model. These variables can be calculated by the natural logarithm of the total assets of a bank.

\section{Equity}

Referring to Chiorazzo et al. (2018) equity is a control variable associated with the characteristics of banks in the model associated with capital adequacy in banks using the leverage ratio calculated by total capital to total assets. Banks with lower levels of equity tend to be riskier.

\section{Loans}

Referring to Chiorazzo et al. (2008), Stiroh and Rumble (2006), and DeYoung and Roland (2001) loans are control variables related to the characteristics of banks in the model related to the bank's ability to lend, which is the ratio of total loans to total assets.

\section{GDP}

Control variables in models related to macroeconomic conditions illustrate the growth of the gross domestic product in Indonesia. This control variable aims to see how the impact of economic growth on a country affects its performance. This variable is calculated by looking at the growth of Indonesia's gross domestic product.

\section{Growth}

Referring to Stiroh (2004) and Chiorazzo et al. (2008) variable growth is the growth of total assets in the bank that can be used to describe the preference of corporate leaders to take risks. High growth rates can show high corporate leader's preference.

\section{Theoretical Framework, Hypothesis, and Model}

Banking companies are considered to have sufficiently experienced many developments, this is also by the fact that the source of bank income has changed a lot in recent years. Moreover in different regions of the world the costs and benefits of combining different types of bank activities increase 
the variety of bank activities that are allowed (Demirgüç-Kunt \& Huizinga, 2010). In addition to the increasing competition in diversified income banking companies, it is also supported by technological developments where banks are beginning to invest in technologies that can increase its non-interest income.

Some studies find that research income diversification produced considerable findings (Peria and Mody, 2004, Acharya, et al. 2016, 2017). Like the results of the research conducted by Stiroh and Rumble (2006) that investigated whether the shifting of activities that resulted in fees, trade revenues, and other non-interest income had improved the performance of financial holding companies (FHC) in the United States from 1997 to 2002. The results of this study found that there is a benefit of income diversification in FHC, but this benefit is reduced by the increased volatility of non-interest activity increases. Other studies focusing on developed countries (Stiroh, 2004, Athanasoglou, et al. (2006), Lepetit et al., 2008, 2006) also addressed the same results. However, several studies that discussed developing countries showed different results (Peria, \& Mody, 2004, Sanya and Wolfe, 2011; Pennathur et al., 2012; Nguyen et al., 2012; Sissy, 2017). Based on the above description, the author developed a hypothesis that the higher the diversification of bank income, then the level of corporate profitability will increase too. So the models and hypotheses used to research the impact of income diversification testing and shifting bank activities on activities that generate non-interest income on bank profitability and risk adjusted-profitability are as follows:

Hypothesis: increased diversification of bank revenues and non-interest incomes enhanced bank profitability.

\section{Model Specification}

Profitability $=\beta_{0}+\beta_{1}(D I V) i+\beta_{2}(C O M M) i+\beta_{3}(T R A D) i+\beta_{2}(O T H) i+Z i t+\varepsilon ;$

Where:

$\begin{array}{ll}\text { Profitability } & =\text { ROA }, \text { and } R O E \\ D I V & =\text { Concentration of income-generating activities } \\ C O M M & =\text { Proportion of commission income to total revenue } \\ T R A D & =\text { Proportion of the trading income to total revenue } \\ \text { OTH } & =\text { Proportion of other income to total revenue } \\ Z_{i t} & =\text { Control Variable } \\ E & =\text { error term } \\ \beta_{O} & =\text { constant } \\ \beta_{X} & =\text { regression coefficient }\end{array}$

\section{Results and Discussion}

The previous model test conducted with Hausman Test indicates the use of Random Effect Model in testing the regression model. The regression results are presented in the Table 1. The Table shows that the diversification of income affects the return on assets and return on equity of the company positively, meaning that the more diversified income of a bank is, then the level of return on the total assets of a bank will increase. The results are consistent with previous research (Lepetit et al., 2008; Sanya \& Wolfe 2011) showed that well-diversified income banks will get a better rate of return, so it can be said that the diversification strategy provides benefits to the bank (Galindo and Bebczuk, 2005; Li and Zhang, 2013; Saghi-Zedek, 2016).

Commission revenue (COMM), trading revenue (TRAD), and other revenue (OTH) variables themselves have a negative relationship to ROA and ROE. The results of this study support the results of research by Mutiara and Irwan (2016) who researched 101 banks in Indonesia during 2004-2009 where the study found a negative influence even if it was not significant. This may be because banks 
in Indonesia have a higher interest margin interest margin if compared with other Asian banks so that the interest income activities can yield greater benefits (Trinugroho et al. 2014). In addition, the other factor is that income from non-interest income generates higher levels of risk, especially in trading activities (DeYoung dan Roland, 2001).

Tabel 1. Regression Result (ROA)

\begin{tabular}{ccc}
\hline Sample Size 180 & Return on Asset & Return on Equity \\
\hline Independen Variabel & Result & Result \\
\hline DIV & 0,2061 & 78,282 \\
& $0,0140^{* *}$ & $0,0040^{* * *}$ \\
COMM & $-0,3854$ & $-147,192$ \\
& $0,0060^{* * *}$ & $0,0010^{* * *}$ \\
TRAD & $-0,3190$ & $-13,0026$ \\
& $0,0410^{* *}$ & $0,0110^{* *}$ \\
OTH & $-0,2517$ & $-99,554$ \\
& $0,0160^{* *}$ & $0,0040^{* * *}$ \\
\hline Control Variabel & & \\
\hline Growth & 0,0074 & 0,2453 \\
& $0,0410^{* *}$ & $0,0440^{* *}$ \\
Loans & $-0,0166$ & $-0,0420$ \\
& $0,0980^{*}$ & 0,8930 \\
Equity & $-0,0244$ & 3,5855 \\
& 0,4170 & $0,0000^{* * *}$ \\
Asset & 0,0050 & 0,1145 \\
GDP & $0,0010^{* * *}$ & $0,0040^{* * *}$ \\
& 0,0043 & 0,2074 \\
Constant & $0,0140^{* *}$ & $0,0140^{* *}$ \\
Adjusted R-Sq & $-0,1254$ & $-43,4040$ \\
& $0,0010^{* *}$ & $0,0000^{* * *}$ \\
\end{tabular}

$*, * *, * * *$ represent significance level at $10 \%, 5 \%$, and $1 \%$ respectively

\section{Conclusion}

In the regression model, the ROA and the ROE reflect the bank's profitability performance. The regression model shows the impact of bank diversification and non-interest income levels. It can be seen from the significance of each independent variable which is revenue diversification (DIV), commission revenue (COMM), trading revenue (TRAD), and other revenue (OTH) variable on the regression model with the return on asset as the dependent variable, where diversification gives benefit to the bank in profitability aspect. This can be seen from the significant revenue diversification (DIV) variable and has a positive influence. However, in banks in Indonesia, it seems that income raising through interest income is still more profitable. This is illustrated by significant, negative all the components of non-interest income, commision revenue (COMM), trading revenue (TRAD), and other revenue $(\mathrm{OTH})$ variables.

It can not be denied that the bank's main income comes from the credits given to the community. However, engaging in activities that result in non-interest exposure is also one of the activities that can generate profits and is still growing. Although the climate of the banking industry in Indonesia which makes non-interest income activities less attractive than interest income, where it is because non-interest income is seen to be riskier while interest margin in Indonesia is higher compared to other countries in ASEAN (Trinugroho et al. , 2014, Mutiara and Irwan, 2016), managers must still be able to create the appropriate income diversification composition of the company, and perform non-interest operating cost efficiencies, so that non-interest income activities can be more 
profitable, and benefit from the diversification of income itself. Because if the bank focuses only on interest income it will increase the risk of the company.

Given the benefits to the diversification strategy found in this study, regulators also have to create regulations that encourage banking companies to perform verifiable strategies, especially in an income diversification strategy.

\section{Refrences}

Acharya, V. V., Le, H. T., \& Shin, H. S. (2017). Bank capital and dividend externalities. Review of Financial Studies, 30 (3), 988-1018.

Acharya, V. V, Hasan, I., Saunders, A., The, S., \& May, N. (2016). Should Banks Be Diversified? Evidence from Individual Bank Loan Portfolios Published by: The University of Chicago Press Stable URL: http://www.jstor.org/stable/10.1086/500679 Your use of the JSTOR archive indicates your acceptance of the Terms \& Condi, 79 (3), 1355-1412.

Athanasoglou, P., Delis, M., \& Staikouras, C. (2006). Determinants of Bank Profitability in The South Eastern European Region. Munich Personal RePEC Archive (MPRA), (10274), 1-32.

Beck, T., Jonghe, O. De, \& Schepens, G. (2012). BANK COMPETITION AND STABILITY: By This is also a Center Discussion Paper This is a revised version of: European Banking Center Discussion Paper Bank competition and stability: Cross-country heterogeneity, (2011).

Chiorazzo, V., Milani, C., \& Salvini, F. (2008). Income diversification and bank performance: Evidence from Italian banks. Journal of Financial Services Research, 33(3), 181-203.

De Jonghe, O. (2010). Back to the basics in banking? A micro-analysis of banking system stability. Journal of Financial Intermediation, 19 (3), 387-417.

Demirgüç-Kunt, A. \& Huizinga, H. 2010. Bank Activity and funding strategies: The impact on risk and returns, Journal of Financiao Economics V0. 98(3), 626-650.

DeYoung, R., \& Rice, T. (2004). Non interest Income and Financial Performance at US. Commercial Banks, 39 (August), 101-127.

DeYoung, R., \& Roland, K. P. (2001). Product Mix and Earning Volatility at Commercial Banks: Evidence from a Degree of Leverage Mode. Journal of Financial Intermediation, 10 (1), 5484.

Froot, K. A. A., \& Stein, J. C. C. (1998). Risk management, capital budgeting, and capital structure policy for financial institutions: an integrated approach. Journal of Financial Economics, 47 (1), 55-82.

Galindo, A., \& Bebczuk, R. (2005). Financial Crisis and Sectoral Diversification of Argentine Bank 1999-2004, Departement of Economics, Working Papers 060, National University of De La Plata.

Gürbüz, A. O., Yanik, S., \& Aytürk, Y. (2013). Income Diversification and Bank Performance: Evidence From Turkish Banking Sector. BDDK Bankacılık ve Finansal Piyasalar, 7 (1), 9-29.

Kamp, A., Pfingsten, A., Memmel, C., \& Behr, A. (2007). Diversification and the Banks' Risk-ReturnCharacteristics - Evidence from Loan Portfolios of German Banks. EFA 2006 Zurich Meetings Paper, (5).

Krismanji. (2017). Strategi Binsis, Leverage Keuangan, dan Kinerja Perusahaan. Jurnal Akutansi dan Auditing Indonesia, 21 (1). 
Kuncoro, M. dan Suhardjono. 2002. Manajemen Perbankan: Teori dan Aplikasi. Edisi Pertama. Yogyakarta: Salemba Empat

Lee, C. C., Hsieh, M. F., \& Yang, S. J. (2014). The relationship between revenue diversification and bank performance: Do financial structures and financial reforms matters. Japan and the World Economy, 29, 18-35.

Lepetit, L., Nys, E., Rous, P., \& Tarazi, A. (2008). Bank income structure and risk: An empirical analysis of European banks. Journal of Banking \& Finance, 32(8), 1452-1467.

Li, L., \& Zhang, Y. (2013). Are there diversification benefits of increasing non interest income in the Chinese banking industry? Journal of Empirical Finance, 24, 151-165.

Mercieca, S., Schaeck, K., \& Wolfe, S. (2007). Small European banks: Benefits from diversification? Journal of Banking and Finance, 31 (7), 1975-1998.

Meslier, C., Tacneng, R., \& Tarazi, A. (2014). Is bank income diversification beneficial? Evidence from an emerging economy. Journal of International Financial Markets, Institutions and Money, 31 (1), 97-126.

Nguyen, M., Skully, M., \& Perera, S. (2012). Journal of International Financial Markets, Institutions \& Money Market power, revenue diversification and bank stability: Evidence from selected South Asian countries. "Journal of International Financial Markets, Institutions \& Money," 22 (4), 897-912.

Mutiara, N, H. \& Irwan, T. (2016). Revenue diversification, performance and bank risk: Evidance from Indonesia, Jurnal Dinamika Manajemen. (36), 139-148.

Phan, H. T. M., Daly, K. and Akhter S. 2016. Bank Efficiency in emerging Asian countries. Research in International Business and Finance, Vol. 38, 517-530.

Pennathur, A. K., Subrahmanyam, V., \& Vishwasrao, S. (2012). Income diversification and risk: Does ownership matter? An empirical examination of Indian banks. Journal of Banking and Finance, 36 (8), 2203-2215.

Peria, M. S., \& Mody, A. (2004). How Foreign Participation and Market Concentration Impact Bank Spreads: Evidence from Latin America. Journal of Money, Credit, and Banking, 511-537.

Rogers, E. W., \& Wright, P. M. (1998). Measuring organizational performance in strategic human resource management: Problems and Prospects (CAHRS Working Paper \#98-09). Cornell University, School of Industrial and Labor Relations, Center for Advanced Human Resource Studies, 1-27.

Rokhim, Rofikoh. (2017). The structure of Indonesian banking and insurance industry. International Journal of Economic Research 14 (12), 187-193.

Saghi-Zedek, N. (2016). Product diversification and bank performance: Does ownership structure matter? Journal of Banking and Finance, 71, 154-167.

Sanya, S., \& Wolfe, S. (2011). Can Banks in Emerging Economies Benefit from Revenue Diversification? Journal of Financial Services Research, 40 (1), 79-101.

Sissy, A. M., Amidu, M., \& Abor, J. Y. (2017). The effects of revenue diversification and cross border banking on risk and return of banks in Africa. Research in International Business and Finance, 40, 1-18.

Smith, R., Staikouras, C., \& Wood, G. (2003). Non-Interest Income and Total Income Stability. Publication Bank of England, 1-40. 
Stiroh, K. J. (2004). Diversification in Banking: Is Noninterest Income the Answer? Journal of Money, Credit, and Banking, 36(5), 853-882.

Stiroh, K. J., \& Rumble, A. (2006). The dark side of diversification: The case of US financial holding companies. Journal of Banking and Finance, 30 (8), 2131-2161.

Trinugroho, I., Agusman, A \& Tarazi, A. 2014. Why Have Bank Interest Margin Been So High in Indonesia Since The 1997/1998 Financial Crisis? Research in International Business and Finance. 32: 139-158.

Va, G. B., \& Ofekb, E. (1995). Diversification effect on firm value. Journal of Financial Economics. 37. 39-65.

Vironika, N.M dan Budiasih 2013. Pengaruh Debt to Equity Ratio, Firm Size, Inventory Turnover dan Assets Turnover pada Profitabilitas. Jurnal Akuntansi Universitas Udayana. ISSN: 2302-8556. No. 5.2 hal.261-273.

Winton, A. (1999). Don't Put All Your Eggs in One Basket? Diversification and Specialization in Lending. SSRN Electronic Journal, (612). 